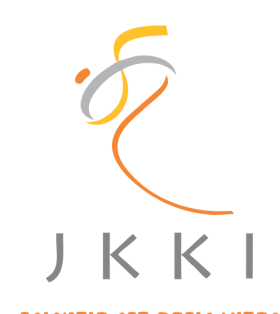

SCIENTIR EST BASIC VITAE

\section{Jurnal Kedokteran dan Kesehatan Indonesia}

\author{
Indonesian Journal of Medicine and Health
}

Journal homepage: https://journal.uii.ac.id/JKKI

\title{
Involvement of lipids in immune system regulation: A mini-review
}

\author{
Kurnia Putri Utami ${ }^{1,2}$, Widya Wasityastuti*1,3, Marsetyawan HNE Soesatyo ${ }^{1,4}$ \\ ${ }^{1}$ Master in Biomedical Science, Faculty of Medicine, Public Health, and Nursing, Universitas Gadjah Mada, Yogya- \\ karta, Indonesia \\ ${ }^{2}$ Department of Physiotherapy, Universitas Muhammadiyah Malang, Malang, Indonesia \\ ${ }^{3}$ Department of Physiology, Faculty of Medicine, Nursing and Public Health, Universitas Gadjah Mada, Yogyakarta, \\ Indonesia \\ ${ }^{4}$ Department of Histology and Cell Biology, Faculty of Medicine, Public Health, and Nursing, Universitas Gadjah \\ Mada, Yogyakarta, Indonesia
}

Article Review

\begin{tabular}{|c|c|}
\hline & ACT \\
\hline ARTICLE INFO & \\
\hline $\begin{array}{l}\text { Keywords: } \\
\text { lipid, } \\
\text { fatty acids, } \\
\text { immune system, } \\
\text { active immune response }\end{array}$ & $\begin{array}{l}\text { body. Maintaining these roles, components of the immune system need } \\
\text { energy obtained from nutrients such as carbohydrates, proteins, and } \\
\text { lipids. This study reviews and discusses roles of lipids, particularly fatty } \\
\text { acids, in regulations of the immune system. This study was conducted }\end{array}$ \\
\hline $\begin{array}{l}\text { *Corresponding author: } \\
\text { wasityastuti@ugm.acid } \\
\end{array}$ & $\begin{array}{l}\text { by conducting a literature study on published research articles written } \\
\text { in English. The articles were obtained from PubMed and Google Scholar }\end{array}$ \\
\hline $\begin{array}{l}\text { DOI: } 10.20885 / \text { KKI.Vol12.Iss1.art9 } \\
\text { History: } \\
\text { Received: April 14, 2020 } \\
\text { Accepted: February 14, } 2021 \\
\text { Online: April 30, 2021 }\end{array}$ & $\begin{array}{l}\text { by using search keywords: lipid, fatty acids, immune, regulation, } \\
\text { inflammation, and response. Lipids are a group of biomolecule compounds } \\
\text { composed of carbon, oxygen, and hydrogen, and they are classified into } \\
\text { simple, compound and complex lipids. Fatty acids are compound lipids }\end{array}$ \\
\hline $\begin{array}{l}\text { Copyright @2021 Authors. } \\
\text { This is an open access article } \\
\text { distributed under the terms } \\
\text { of the Creative Commons At- } \\
\text { tribution-NonCommercial } 4.0 \\
\text { International Licence (http:// } \\
\text { creativecommons.org/licences/ } \\
\text { by-nc/4.0/). }\end{array}$ & $\begin{array}{l}\text { that act as a main fuel for metabolism, an essential component for all } \\
\text { membranes, and a gene regulator. Fatty acids have a modulating effect } \\
\text { on immune cells, such as: acting as a host defence, activating the immune } \\
\text { system, interacting with nuclear transcription factors, playing roles in } \\
\text { inflammatory responses, promoting apoptosis, as well as influencing } \\
\text { lymphocyte proliferation, cytokine production, and Natural Killer (NK) } \\
\text { cell activities. However, the modulation of the immune system by lipids } \\
\text { is influenced by various factors such as concentration and types of fatty } \\
\text { acids, types of immune cells, and species. This study is suggested to } \\
\text { provide an overview of beneficial roles of lipids in maintaining immunity. }\end{array}$ \\
\hline
\end{tabular}

$\overline{\text { Sistem imun merupakan sistem yang bekerja untuk mengenali dan melawan antigen yang masuk ke dalam }}$ tubuh. Untuk menjalankan peran ini, komponen sistem imun memerlukan energi yang diperoleh dari nutrisi seperti karbohidrat, protein, dan lipid. Review ini membahas peran lipid, khususnya asam lemak, dalam regulasi sistem imun. Penyusunan review dilakukan dengan melakukan studi literatur terhadap jurnaljurnal ber-Bahasa Inggris yang diperoleh dari pencarian di database PubMed dan Google Scholar dengan kata kunci: lipid, fatty acids, immune, regulation, inflammation, dan response. Lipid adalah kelas biomolekul untuk senyawa yang tersusun atas karbon, oksigen, dan hydrogen, terbagi menjadi lipid sederhana, majemuk dan kompleks. Asam lemak merupakan bagian dari lipid majemuk yang berperan sebagai bahan bakar utama metabolisme, komponen esensial untuk semua membran, dan sebagai regulator gen. Asam lemak memiliki efek modulator pada sel imun, antara lain: sebagai host defense, mengaktivasi sistem imun, berinteraksi dengan faktor transkripsi nukleus, berperan dalam reaksi inflamasi, memicu apoptosis, dan memengaruhi proliferasi limfosit, produksi sitokin, dan aktivitas sel Natural Killer (NK). Meskipun 
begitu, modulasi sistem imun oleh lipid dipengaruhi oleh berbagai faktor seperti konsentrasi dan jenis asam lemak, jenis sel imun, dan spesies. Informasi ini kami harapkan dapat memberikan gambaran pemanfaatan lipid untuk menjaga kekebalan tubuh.

\section{INTRODUCTION}

Humans can fight against various antigens such as bacteria, viruses, other microbes, or destructive toxins. This ability is played by an immune system which regulates the protective mechanisms against diseases by identifying and killing pathogens entering the body. This protection is provided by lymphoid tissue, immune cells with specific effector cells, and chemical substances. These components work together to maintain immunity.

The immune system is divided into two, an innate immune system (innate immunity) and an adaptive immune system (adaptive immunity). These two systems interact with each other to give protection through the activation and proliferation of immune cells as well as the synthesis and secretion of molecules and proteins, and all these processes require energy. In relation with supply of energy, either lack or excess of nutrients it will have impacts on the immune response or body defence. The nutrient imbalance may compromise the immune system so that the body becomes more susceptible to infection, diabetes, and cancer.

Lipids, a component that plays a role in nutritional status, have many functions and are not only limited to providing energy. Their roles include signal delivery, apoptosis, proliferation, differentiation, and cell growth in normal and pathological physiological conditions. ${ }^{1,2}$ Inside the cells, lipids are stored in a form of lipid droplets (LDs) which can provide metabolic energy for various cellular processes such as membrane synthesis and molecular signalling. Lipids, which are one of the main components of cell membranes, cell nuclei, and organelles, facilitate structural changes that occur during cell proliferation. The energy generated from burning intracellular lipids can trigger an increase in cell proliferation. Several types of lipids such as cholesterol and ceramide are known to increase the proliferation of various types of cells. Besides, lipids are also involved in apoptotic processes, either by inhibiting apoptosis for example through the integrin signalling pathway or promoting apoptosis which is triggered by several types of fatty acids through an induction of endoplasmic reticulum (ER) stress or transcription regulation. However, lipids can also harm the body when an infection occurs because several pathogens are known to utilize intracellular LDs to proliferate and survive, for example, the Hepatitis $C$ virus (HCV). ${ }^{3}$

Lipids also play important roles in the immune system. Some of the roles are as intercellular and intracellular mediators in signal transduction to maintain homeostasis, immune response, and inflammation. ${ }^{4}$ Lipids influences the modulation of the immune system by modifying the immune response through cytokine production, natural killer (NK) cell activity, phagocytosis, expression of markers on the cell surface, etc. ${ }^{5,6}$ Thus, maintaining lipid homeostasis will be beneficial for the modulation of the immune system.

To examine roles of lipids in the regulation of the immune system, this narrative review was compiled through literature reviews. The literatures were obtained from published articles in the PubMed and Google Scholar databases with main keywords: lipids, fatty acids, immune, regulation, inflammation, and response. The used articles were only those written in English and are available in a full text in a pdf format. The selection of articles was based on a pre-arranged writing framework. In addition to published articles, the author also used textbooks related to the topic of this study.

\section{LIPID STRUCTURE AND CLASSIFICATION}

Biomolecule compounds of lipids are composed of carbon, oxygen, and hydrogen and are soluble in non-polar solutions. Lipids can be divided into three classifications based on their constituent components, namely simple lipids, compound/complex lipids, and derived lipids. The first lipids, simple lipids, contain 
alcohol and fatty acid groups such as fat, oil, and wax. Compound lipids or complex lipids are combinations of lipids with other molecules, such as phospholipids and glycolipids. Meanwhile, derived lipids are produced from hydrolysis of simple lipids and compound lipids which still have compounds like fat, for example, steroids and terpenes. ${ }^{7}$

\section{Fatty acid}

Fatty acids, a part of compound lipids, provide a major role in metabolic processes. The fatty acids function as a main fuel for metabolism, an essential component for all membranes, and as a gene regulator. Fatty acids can be classified into three types based on the number of carbon atoms and the number of double bonds, namely saturated fatty acids (SFA), monounsaturated fatty acids (MUFA), and polyunsaturated fatty acids (PUFA). ${ }^{7}$ Saturated fatty acids have no double bonds (for example stearic acids) whereas unsaturated fatty acids have one or more double bonds (for example oleic acids, n-3, and n-6 linoleic acids) (Figure 1).

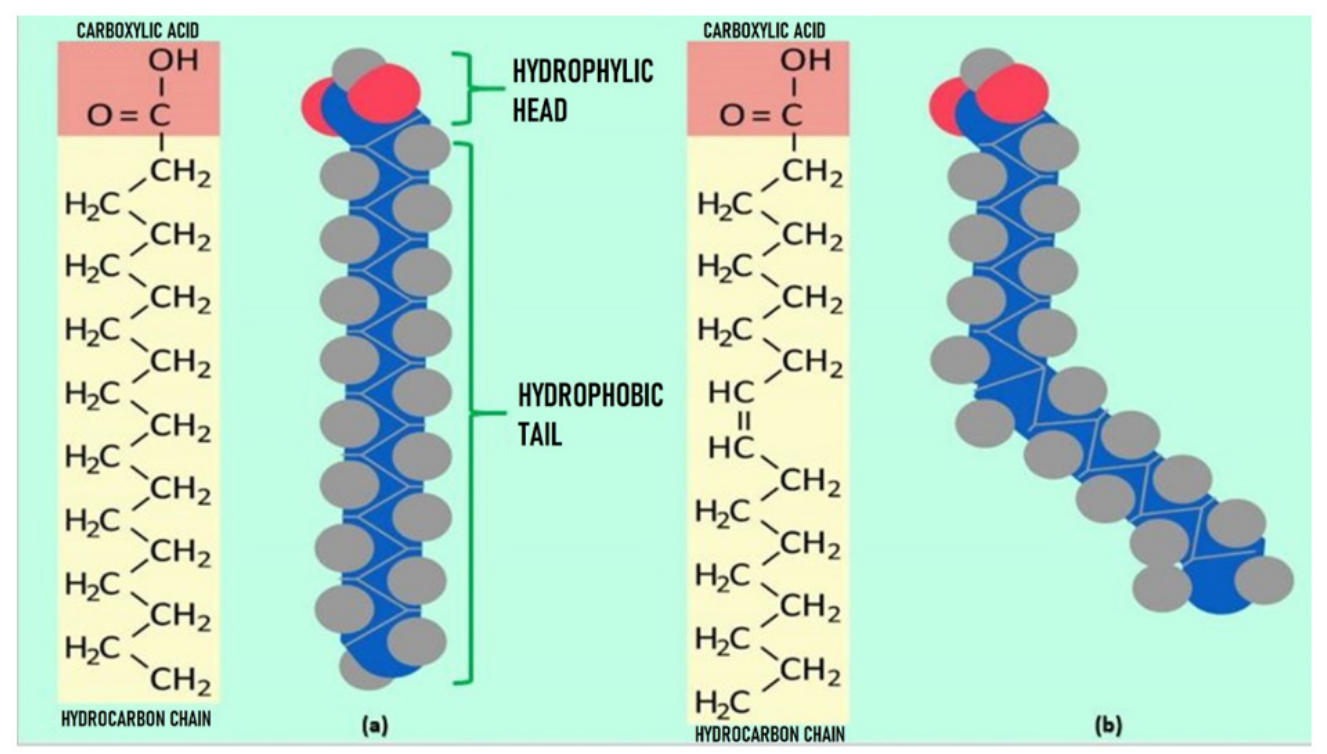

Figure 1. Fatty acid structures. ${ }^{7}$ This compound is a carboxylic acid composed of long hydrocarbon chains with a chemical formula of R-COOH or R-CO2H with a structure consisting of a hydrophilic head and a hydrophobic tail section.

(a) Saturated fatty acids; (b) Unsaturated fatty acids.

Saturated fatty acid receptors are widely expressed in several immune cells such as neutrophils, macrophages, and dendritic cells, indicating the roles of fatty acids in activities of the immune system. ${ }^{8}$ Fatty acids also modulate some immune responses that can prevent some disorders and reduce incidences of inflammation and autoimmune diseases. For example, fish oil containing n-3 PUFA is known to have immunosuppressive effects by reducing lymphocyte proliferation, neutrophil chemotaxis, and secretion of several cytokines such as IL-1, IL-2, and TNF5. However, n-3 PUFA also acts as an immunomodulator because it can increase Treg differentiation and phagocytic activities of macrophages and neutrophils. ${ }^{9}$

\section{EFFECTS OF LIPID MODULATORS AND FATTY ACIDS ON IMMUNE CELL FUNCTIONS Roles of lipids in Host Defence}

Several classes of lipids which are immunosuppressive such as n-3 PUFA can cause controversies because they allow a decrease in the body's defence against infections. In an 
in vitro setting, eicosapentaenoic acid (EPA) and docosahexaenoic acid (DHA) are reported to inhibit the production of actin which can worsen the body's defence against pathogens. ${ }^{10}$ However, several other types of lipids that are often found in cells (for example, arachidonic acid, ceramide, and sphingosine) can stimulate actin nucleation around phagosomes, thereby triggering phagosome fusion with endocytic organelles in macrophages infected by pathogens. ${ }^{10,11}$ This shows the roles of lipids in increasing the ability of the immune system to kill pathogens. In patients infected with Human Immunodeficiency Virus (HIV), n-3 PUFA can increase the number of patients who survive and decrease the inflammatory responses. ${ }^{4}$ However, further research is needed to determine the effects of n-3 PUFA on the body's defence against pathogens.

\section{Lipids in immune system activation}

A lipid raft, a component of a plasma membrane, plays a role in the immune system by serving as the microenvironment for intercellular communication. It is composed of phospholipid bilayers that are rich in saturated fatty acids, sphingolipids, cholesterol, and glycosylphosphatidylinositol (GPI) proteins, playing roles in intercellular communication as well as in intracellular pathways of lipids and proteins. ${ }^{8}$ Various types of receptors and enzymes that play roles in maintaining cell life are known to be closely related to the lipid raft. ${ }^{12}$ The raft serves as a location of signal receptors for signal transduction. ${ }^{13}$ This signal transduction will facilitate cell migration, link molecular signals, and play a role in cell interaction. Proteins in the raft that are activated by extracellular ligands initiate intracellular signaling. The activation of protein in the raft by extracellular ligands is essential for signal transduction in $\mathrm{T}$ and $\mathrm{B}$ lymphocytes. For example, the $\mathrm{T}$ cell receptors in the raft interact with antigen-presenting cells (APCs) and form an immunological synapse. ${ }^{10}$ This is a basis of the role of lipids in $\mathrm{T}$ cell activation. However, the role of a raft on $\mathrm{T}$ cell receptor activation is different between Th1 and Th2 cells. In Th1 cells, activation is raft-dependent, whereas in Th2 cells it is independent of raft. The reasons for these differences are unclear, but they may be caused by differences in the composition, distribution, or quantity of the lipid raft. ${ }^{8}$ When the lipid composition of the lipid raft changes, the structure and fluidity of the membranes are affected: for example, it occurred in T cells isolated from patients with autoimmune diseases such as systemic lupus erythematosus (SLE) and rheumatoid arthritis (RA). ${ }^{12-14}$

\section{Lipid interactions and nuclear transcription factors on immune cells}

Lipids work well with transcription factors to produce immune cells. Fatty acids regulate gene transcription which affects metabolism, proliferation, and cell death. ${ }^{15}$ One of the receptors that are influenced by fatty acids is the Peroxisome Proliferator-Activated Receptors (PPARs) which can activate transcription factors and which are presented in various cell types with different functions (Figure 2). The receptors bind to the DNA of immune cells and influence gene expression in these cells through interactions with other transcription factors and by inhibiting (trans-repression) or increasing (trans-activation) their binding to DNA. Peroxisome Proliferator-Activated Receptor- $\gamma$ and $-\alpha$ have been shown to inhibit the production of monocytic cell cytokines indicating their anti-inflammatory function. The $\alpha$ type receptor is a predominant isoform expressed on $\mathrm{T}$ and $\mathrm{B}$ lymphocytes, whereas PPAR $\gamma$ is mainly produced in myeloid cells. PPAR $\gamma$ ligand can decrease production of interferon- $\gamma$ (INF- $\gamma$ ) and IL-2 and inhibit T10 cell proliferation.

As natural ligand of PPARs, fatty acids may trigger PPAR- $\alpha$ gene transcription. The increase in PPAR- $\alpha$ activation causes an increase of energy-burning and a decrease in fat storage: as a result, PPAR- $\alpha$ can be used as a lipid and metabolism sensor. ${ }^{16}$ A study showed that phospholipid components of oxidized low- 
density lipoprotein (ox-LDL) can trigger formation of lipid bodies in macrophages, it serves as a basis that induction of lipid body formation by this component also activates
PPARs. ${ }^{10}$ This supports the role of fatty acids as PPARs ligand that act on both innate and adaptive immune systems.

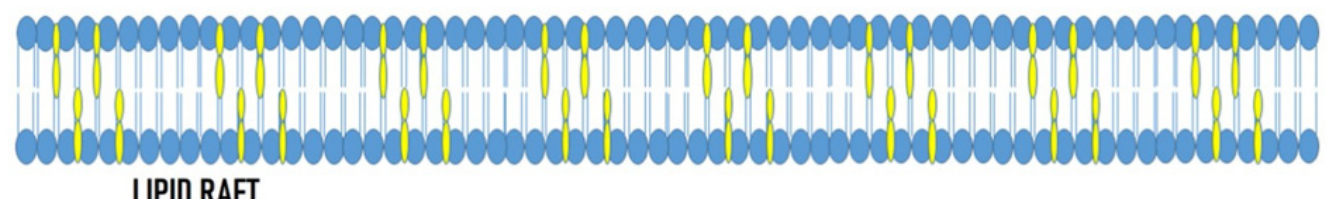

LIPID RAFT

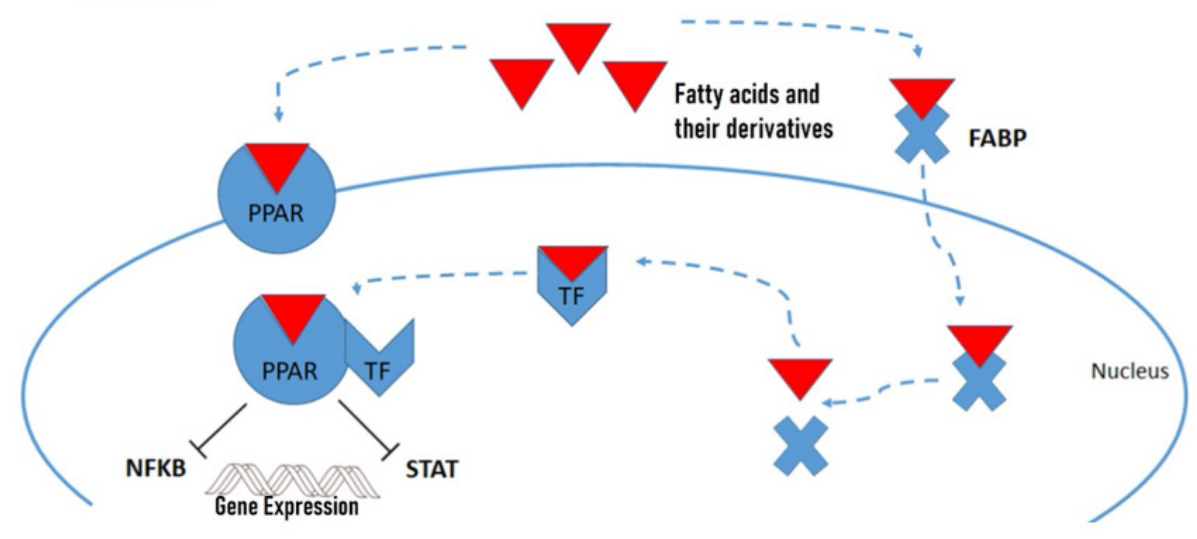

Figure 2. Fatty acid pathways in cell regulations. ${ }^{10,15,16}$

PPARs: Peroxisome Proliferator-Activated Receptors;

TF: Transcription Factors;

FABP: Fatty Acid Binding Protein;

NFKB: Nuclear factor- $\kappa B$;

STAT: signal transducer and activator of transcription.

Fatty acids, n-3 PUFAs in particular, influence $B$ cell activation and antibody production by interacting with transcription factors to alter expression of targeted genes. Currently, the role of n-3 PUFA on B cells is controversial. Although most studies showed that n-3 PUFA can decrease $B$ cell activation, some studies also reported that administering n-3 PUFA can increase expression of $\mathrm{B}$ cell activation biomarkers such as CD69, MHC II, and CD11c. DHA and EPA may enhance IgM production by increasing the number of cells that produce antibodies. ${ }^{14}$ However, this effect is specific only for IgM because n-3 PUFA does not affect the production of IgA, IgG, or IgD by B14 cells.

\section{Roles of lipids in the inflammatory reactions of the immune system}

Inflammation is one of the immune system responses to tissue damage and a reaction against foreign antigens. When there is an injury to the tissue, the body will activate a haemostasis system to prevent bleeding and improve the condition of the tissue. In the haemostasis process, lipids may produce eicosanoids, a molecule for platelet aggregation and cell movement. ${ }^{5,15}$ Phospholipase releases fatty acids from the plasma membrane and then these fatty acids will undergo enzymatic degradation and produce eicosanoids, by immune cells from both innate and adaptive immune systems.

Mechanisms of eicosanoid production involve oxidation of arachidonic acid or EPA helped by cyclooxygenase enzymes (COX) and lipoxygenase (LOX). These types of eicosanoid precursors determine whether the molecules produced will promote or inhibit inflammation 
(Figure 3). Arachidonic acid-derived eicosanoids, such as prostaglandin E2 and leukotriene B4, participate in inflammatory responses by modulating lymphocyte proliferation, cytokine production, and cytotoxicity that induces inflammation. ${ }^{5,8}$ Eicosanoids produced by EPA, such as prostaglandin E3, have opposite effects of inhibiting the proliferation of macrophages and lymphocytes. ${ }^{17,18}$ Because of a high content of arachidonic acid in phospholipid membranes of cells involved in the inflammatory process, arachidonic acid is the main precursor for the formation of eicosanoids. The eicosanoid profile that is formed depends on nature of stimuli and the types of immune cells that produce it: for example, neutrophils and mast cells produce more prostaglandin D2 while monocytes synthesize more prostaglandin E2. Eicosanoids from the EPA precursor have a different structure from the eicosanoids of arachidonic acid; this structural difference affects their effectiveness. Eicosanoids from EPA often have significantly lower biological activity than eicosanoids from arachidonic acid. ${ }^{18}$

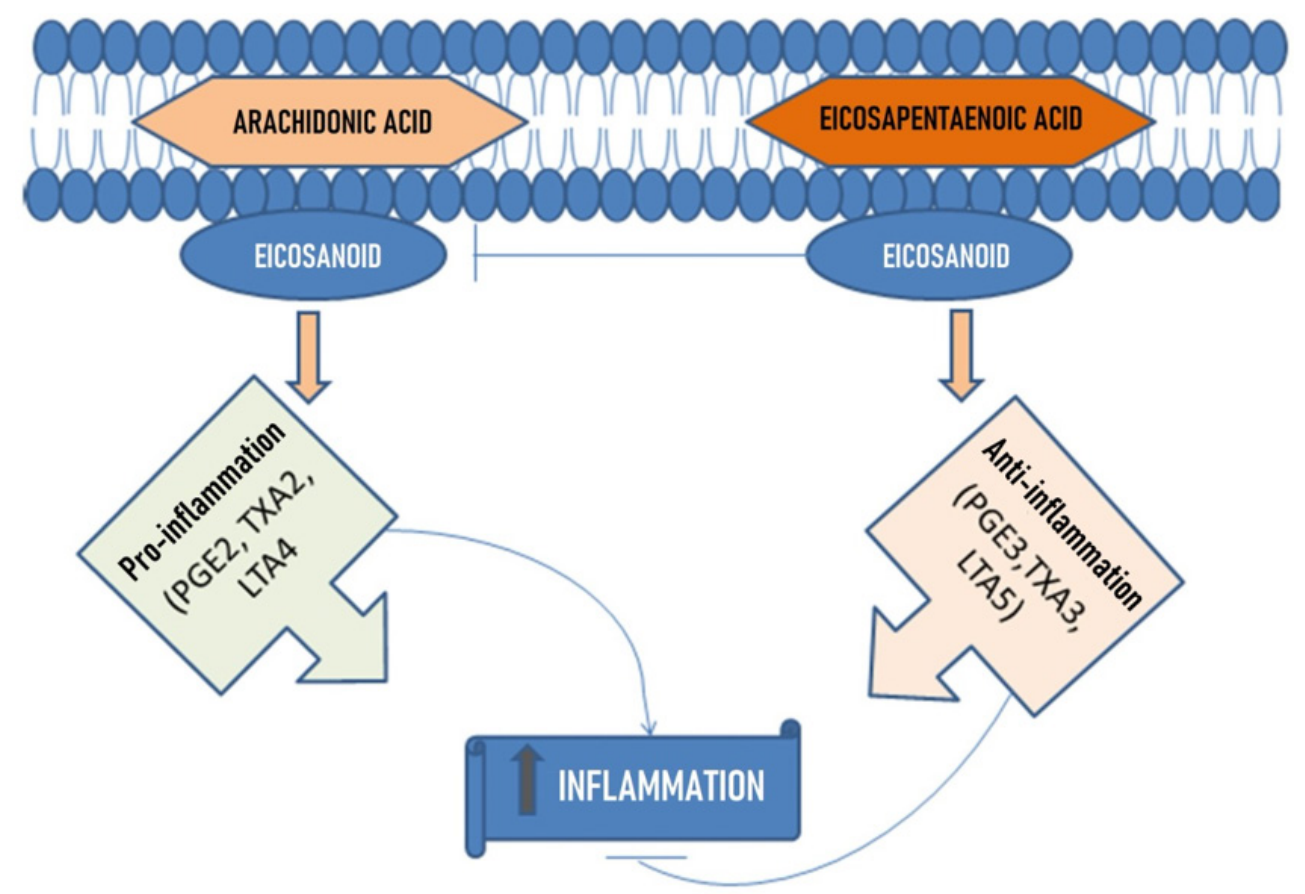

Figure 3. Dual roles of fatty acids in inflammation. 8,17,18

\section{Effects of fatty acids on lymphocyte proliferation}

Fatty acids influence the proliferation and regulation of lymphocyte cell activities. In both animals and humans, some studies have shown that unsaturated fatty acids can reduce lymphocyte cell proliferation. .,14,19,20 $^{2}$ Unsaturated fatty acid compounds, such as EPA and DHA, suppress lymphocyte mitogen responses better than saturated fatty acids. Monounsaturated fatty acids, such as oleic acid, also play a role in immunomodulatory processes but their regulatory effects are not as strong as saturated fatty acid compound. ${ }^{5}$ This suggests that these types of fatty acids exert different regulatory effects on immune cells.

A study in mice showed a significant difference of the suppressive effects of unsaturated fatty acids on lymphocytes in the spleen and thymus. The suppressive effect to thymic lymphocytes is less than that of the spleen. ${ }^{19}$ This study shows that apart from the types of fatty acids, the subpopulation of lymphocytes also affects the effects of fatty acids on lymphocytes.

Other studies suggest that the concentration 
of fatty acids also affects lymphocyte proliferation. ${ }^{5,14,20}$ In ex vivo studies, it was found that there was a decrease in lymphocyte proliferation which was influenced by high concentrations of n-3 or n-9 unsaturated fatty acids. ${ }^{5,14}$ Animal studies also showed that a high-fat diet reduces lymphocyte cell functions compared to a low-fat diet, but this also depends on the type and source of fatty acids. ${ }^{20}$

The roles of fatty acids on lymphocytes are a basis for clinical application through diet management in patients with autoimmune diseases. Rheumatoid arthritis patients in Mediterranean countries are not as severe as in other countries because the population consumes a lot of fish oil and olive oil. ${ }^{21}$ Fish oil containing omega 3 is known to have immunosuppressive effects by reducing lymphocyte proliferation, neutrophil chemotaxis, and secretion of several cytokines such as IL-1, IL-2, and TNF. ${ }^{5,14}$ This shows that fatty acids can be used to treat diseases caused by excessive activation of the immune system and to fight the body itself after infections or injuries.

\section{Effects of fatty acids on cytokine production}

Cytokines are biochemical mediators that regulate immune cell homeostasis and coordinate immune responses. These cytokines are produced by several types of cells such as B cells, T cells, macrophages, mast cells, neutrophils, basophils, and eosinophils. Different types of cells can produce the same cytokines and one type of cytokines can act on several types of immune cells. Cytokines can work synergistically or antagonistically. Cytokine antagonist performance is a negative feedback mechanism that allows tissue to return to its normal (non-inflammatory) state. Proinflammatory cytokines provide a signal to the immune system when an antigen enters: consequently, the dysregulation of cytokine production can cause disorders of the immune system, such as autoimmune diseases. ${ }^{22}$

The component of fatty acids modulates lymphocyte functions to proliferate and produce cytokines. Saturated fatty acids (palmitic and stearic acids) affect cytokine production more significantly than unsaturated fatty acids (oleic and linoleic acids). These polyunsaturated fatty acids are reported to inhibit the production of the cytokine IL-2, which plays an important role in lymphocyte proliferation. This inhibitory effect of proliferation by n-3 PUFA is mediated by the inhibition of CD25 expression which is the IL-25 receptor. ${ }^{5,23}$ Another study suggested that lipid rafts in plasma membranes also play a role in IL-2 signal transduction. ${ }^{24}$ Immobilization of raft lipid components, such as glycosylphosphatidyl-inositol - anchored proteins and monocsialotetrahexosylganglioside (GM1), inhibits $\mathrm{T}$ cell proliferation by regulating IL-2 signalling. Raft lipids can decrease IL-2 production by inhibiting extracellular signal-regulated kinase (ERK) activation and phosphorylation of tyrosine protein in $\mathrm{T}$ cell receptor. ${ }^{24}$ Moreover, other studies have also shown that triglycerides and cholesterol affect production or secretion of the cytokine IL-1 $\beta$ by activating inflammasomes and n-3 PUFA can reduce differentiation of Th17 cells so that IL-17 production by these cells decreases. ${ }^{9,25}$

Production of proinflammatory cytokines, such as IL-1, IL-2, IL-6, and TNF, significantly increases when there is trauma or invasion of pathogenic organisms. Although this cytokinemediated immune response is very important, overproduction of proinflammatory cytokines is often associated with various diseases such as malaria, sepsis, inflammatory bowel disease, rheumatoid arthritis, and AIDS. Hence, many studies have examined the antiinflammatory effects of fish oil rich in $n-3$ PUFA. ${ }^{26}$ Administration of $n-3$ PUFA showed a significant decrease in proinflammatory cytokine levels, but these levels would return to their original levels if the administration is stopped. ${ }^{5,14}$ The production of IL-1 and TNF- $\alpha$ cytokines by macrophages in tumour cases can also be inhibited by administering n-3 PUFA. ${ }^{27,28}$

The roles of fatty acids in reducing levels of proinflammatory cytokines are also influenced by the cell population and types of species. 
Although this modification of cytokine synthesis is still unclear, the mechanism can be related to regulation of transcription levels, namely a decrease in cytokine mRNA production by $n-3$ PUFA, especially DHA. ${ }^{29}$

Table 1. Effects of fatty acids on immune system function ${ }^{29}$

\begin{tabular}{|c|c|c|c|}
\hline Fatty Acids (FA) & Source & Target Immune Cells & Function \\
\hline FA 20: 4, 20: 5, 22: 6 & $\begin{array}{l}\text { Endogenous, } \\
\text { supplements }\end{array}$ & Neutrophils & $\begin{array}{l}\text { Attaches to the endothelium } \\
\text { (CD11a and CD11b) }\end{array}$ \\
\hline FA 18: 3 n-3 & Supplement & Alveolar macrophages & $\begin{array}{l}\text { Increases phagocytosis and } \\
\text { TNF- } \alpha \text { production }\end{array}$ \\
\hline FA 18: $3 n-3$ & Oral & $\mathrm{T}$ cells & $\begin{array}{l}\text { Suppresses T cell } \\
\text { proliferation }\end{array}$ \\
\hline FA 20: 4 & $\begin{array}{l}\text { PLA2-II mediated } \\
\text { arachidonic acid release }\end{array}$ & Neutrophils & $\begin{array}{c}\text { Increases Max-1 expression } \\
\text { (CD11b / CD18) }\end{array}$ \\
\hline $\begin{array}{l}\text { FA 18: 0, 18: 2, 18: } 3 \text {, } \\
20: 4\end{array}$ & Endogenous & $\begin{array}{l}\text { Macrophages and } \\
\text { hepatocytes }\end{array}$ & $\begin{array}{c}\text { PPAR- } \alpha \text { and PPAR- } \gamma \text { ligand } \\
\text { bond activators }\end{array}$ \\
\hline FA 18: 2 n-6 & Food sources & Dendritic cells & $\begin{array}{l}\text { Reduces lymph node } \\
\text { infiltration and activation of } \\
\mathrm{T} \text { cells }\end{array}$ \\
\hline FA 20: 5 & Synthetic & Mast cells & $\begin{array}{l}\text { Increased IL-10 and } \\
\text { decreased IL-12 }\end{array}$ \\
\hline FA 22: $6 n-3$ & Synthetic & Dendritic cells & $\begin{array}{l}\text { Increased IL-12, decreased } \\
\text { IL- } 6 \text { and IL-10 }\end{array}$ \\
\hline
\end{tabular}

Note: Endogenous / supplement - fatty acids added to in vivo studies or enriched in vitro test formulations; Synthetic - fatty acids are used in the in vitro test; PLA2-phospholipase A2.

\section{Effects of fatty acids on Natural Killer (NK) cell activities}

NK cells are a component of innate immunity that comes from lymphocytes and plays a role in protection against viruses, intracellular bacteria, and other pathogens that harm the body. Fatty acids can modulate NK cell activities by decreasing activities of these cells. An increase in NK cell activities has been described in a condition of decreased fatty acid intakes. In experimental animals, n-3 fatty acids decreased NK cell activities. In addition, studies conducted in humans by injecting triglycerides intravenously or consuming fish oil containing EPA also show decreased NK cell activities., ${ }^{5,21}$ Activated cells are utilized clinically in the bone marrow and organ transplants to decrease NK cell activities because NK cells play a role in rejection of these transplants. ${ }^{30}$

\section{Lipid-induced apoptosis}

Different classifications of lipids exhibit different roles. In addition to cell proliferation, lipids also play a role in an apoptosis process. The apoptosis can occur through two pathways, namely an intrinsic pathway played by mitochondria and an extrinsic pathway induced by death receptors. These apoptotic pathways can be influenced by lipid metabolism.

Fatty acid oxidation can cause mitochondrial dysfunction and ultimately can trigger apoptosis due to an increase of Reactive Oxygen Species (ROS) in mitochondria. ${ }^{1}$ One of the types of fatty acids that trigger apoptosis is palmitic acid (saturated fatty acid) and EPA. The first Palmitic acid induces cell death by eliminating the mitochondrial transmembrane potential that triggers nuclear apoptosis. High doses of eicosapentaenoic acids have been reported to induce apoptosis in U937-1 monocyte 
cultures. This molecule inhibits proliferation of the monocytes and initiates the apoptosis of these cells at the same time. Since fatty acids are known to activate PPAR receptors, EPA likely affects these monocytes via the PPAR signalling pathways. High levels of EPA in cells can also alter expression of genes that regulate proliferation and apoptosis. ${ }^{5}$ Lipids on the plasma membrane can also induce apoptosis. A presence of disturbances in the raft, such as changes in cholesterol concentration in plasma membranes, will inhibit Akt and activate membrane death receptors (such as Fas and TRAIL) that contributes to increased sensitivity to stimulation of apoptosis as shown in Figure $4 .^{31}$ Although the effect of lipids as a trigger for apoptosis has been proven, mechanisms and types of lipids that induce apoptosis still need to be studied further because of different signalling pathways.

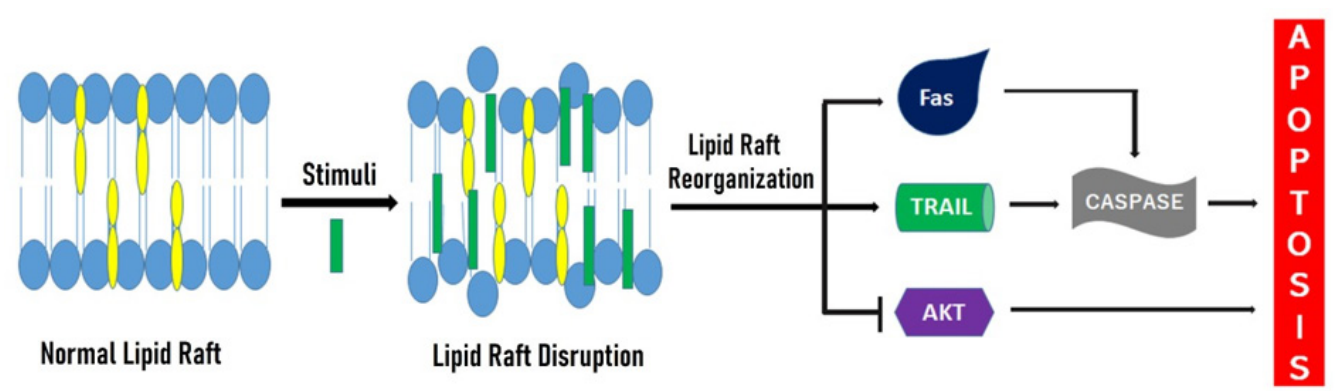

Figure 4. A lipid raft-mediated apoptotic pathway involving activation of the membrane death receptors. ${ }^{32-33}$

\section{CONCLUSION}

Lipids, especially fatty acids, play an important role in maintaining the homeostasis of the body's immune system. This Fatty acids are involved in the activation or suppression of the immune system, either by producing eicosanoids, interacting with transcription factors, affecting lymphocyte proliferation and cytokine production, influencing NK cell activity, or inducing apoptosis in certain immune cells. Modulation or suppression of the immune system by fatty acids is influenced by various factors such as the concentration and types of fatty acids, types of immune cells, species, and others. The factors that influence lipid modulation in the immune system can be used as a guide for the utilization of fatty acids in maintaining immune activities. The use of several types of fatty acids as additional therapy has been conducted. However, it is necessary to study other types of fatty acids that are beneficial to the human body, especially in the immune system.

\section{CONFLICT OF INTEREST}

All authors state that there is no conflict of interest regarding this study.

\section{ACKNOWLEDGEMENT}

The author thanks Fajar Dwi Astarini and Andika Dhamarjati who had assisted in drafting the manuscript and preparing illustrations for this study.

\section{REFERENCES}

1. Huang C, Freter C. Lipid Metabolism, Apoptosis and Cancer Therapy. International Journal of Molecular Sciences. 2015;16(1):924-49.

2. Mignard V, Lalier L, Paris F. et al. Bioactive lipids and the control of Bax pro-apoptotic activity. Cell Death Disease. 2014;5:e1266.

3. Fujimoto T, Parton RG. Not just fat: The structure and function of the lipid droplet. Cold Spring Harbor Perspectives in Biology. 2011;3(3):a004838.

4. Bernardi S, Marcuzzi A, Piscianz E, Tommasini A, Fabris B. The complex interplay between lipids, immune system and inter- 
leukins in cardio-metabolic diseases. International Journal of Molecular Sciences. 2018;19:4058.

5. Pablo D, Cienfuegos A. Modulatory effect of dietary lipids on immune system function. Immunology and Cell Biology. 2000;78(1):31-9.

6. Watson RR, Zibadi S, Preedy VR. Dietary components and immune function. New York: Springer Science \& Business Media, 2010.

7. Rodwell VW, Bender DA, Botham KM, Kennely PJ, Weil PA. Harper's Illustrated Biochemistry 13th Ed. New York: McGraw Hill Companies, 2015.

8. Curto A, Milligan G. Metabolism meets immunity: The role of fatty acid receptor in the immune system. Biochemical Pharmacology. 2016;114:3-13.

9. Kim JY, Lim K, Kim KH, Kim JH, Choi JS, Shim SC. N-3 polyunsaturated fatty acids restore Th17 and Treg balance in collagen antibody-induced arthritis. PLoS ONE. 2018;13(3):e0194331.

10. Yaqoob P. Fatty acids as gatekeepers of immune cell regulation. Trends in Immunology. 2003;24(12):639-45.

11. Melo RCN, Dvorak AM. Lipid Body-Phago some interaction in Macrophages during infectious diseases: Host defense or pathogen survival strategy? PLoS Pathogen. 2012;8(7):e1002729.

12. Sezgin E, Levental I, Mayor S, Eggeling C. The mystery of membrane organization: Composition, regulation and roles of lipid rafts. Nature Reviews Molecular Cell Biology. 2017;18:361-374.

13. Wang X, Kulka M. N-3 polyunsaturated fatty acids and mast cell activation. Journal of Leukocyte Biology. 2015;97(5):859-71.

14. Gutiérrez S, Sara L Svahn SL, Johansson ME. Effects of Omega-3 fatty acids on immune cells. International Journal of Molecular Sciences. 2019;20:5028.

15. Sears B, Ricordi C. Role of fatty acids and polyphenols in inflammatory gene transcription and their impact on obesity, metabolic syndrome and diabetes. European Review for Medical and Pharmacological
Sciences. 2012;16(9):1137-1154.

16. Grygiel-Gornial B. Peroxisome proliferator-activated receptors and their ligands: Nutritional and clinical implications - a review. Nutrition Journal. 2014;13:17.

17. Flock M, Rogers C, Prabhu K, KrisEtherton P. Immunometabolic role of long-chain omega-3 fatty acids in obesity-induced inflammation. Diabetes Metabolism Research and Reviews. 2013;29(6):431-45.

18. Calder P. Omega-3 fatty acids and inflammatory processes. Nutrients. 2010;2 (3):355-74.

19. Yaqoob P, Newsholme E, Calder P. The effect of dietary lipid manipulation on rat lymphocyte subsets and proliferation. Immunology. 1994;82(4):603-10.

20. de Jong AJ, Kloppenburg M, Toes REM, Ioan-Facsinay A. Fatty acids, lipid mediators, and T-cell function. Frontiers in Immunology. 2014;5:483.

21. Skoczyńska M, Świerkot J. The role of diet in rheumatoid arthritis. Reumatologia. 2018;56(4):259-67.

22. Zhang JM, An J. Cytokines. Inflammation, and pain. International Anesthesiology Clinics. 2007;45(2):27-37.

23. Soyland E, Lea T, Sandstad B, Drevon A. Dietary supplementation with very long chain n-3 fatty acids in man decreases expression of the interleukin-2 receptor (CD25) on mitogen-stimulated lymphocytes from patients with inflammatory skin diseases. European Journal of Clinical Investigation. 1994;24(4):236-42.

24. Nagy E, Mocsar G, Sebestyen V, Volko J, Papp F, Toth K, Damjanovich S, et al. Membrane potential distinctly modulates mobility and signaling of IL-2 and IL-15 receptors in T Cells. Biophysical Journal. 2018;114:24732482.

25. Tall AR, Yvan-Charvet L. Cholesterol, inflammation and innate immunity. Nature Review Immunology. 2015;15(2):104116.

26. Grimble RF, Tappia PS. Modulation of pro-inflammatory cytokine biology by unsaturated fatty acids. Z Ernahrungswiss. 1998;37 Suppl 1:57-65. 
27. Gu Z, Shan K, Chen H, Chen YQ. n-3 Polyunsaturated fatty acids and their role in cancer chemoprevention. Current Pharmacology Reports. 2015;1(5):283-294.

28. Calviello G, Su H, Weylandt K, Fasano E, Serini S, Cittadini A. Experimental evidence of \{omega\}-3 polyunsaturated fatty acid modulation of inflammatory cytokines and bioactive lipid mediators: Their potential role in inflammatory, neurodegenerative, and neoplastic diseases. BioMed Research International. 2013; 2013:743171.

29. Kumar NG, Contaifer D, Madurantakam P, Carbone S, Price ET, Tassell BV, Brophy DF, Wijesinghe DS. Dietary Bioactive Fatty Acids as Modulators of Immune Function: Implications on Human Health. Nutrients. 2019;11(12): 2974-2989.

30. Bie N, Han L, Meng M, Zhang Y, Guo M, Wang C. Anti-tumor mechanism of eicosapentaenoic acid (EPA) on ovarian tumor model by improving the immunomodulatory activity in F344 rats. Journal of Functional Foods. 2020;65:103739.

31. Gniadecki R, Poumay Y. Lipid rafts and keratinocyte apoptosis: Regulation via death receptors and akt. The Open Dermatology Journal. 2009;3:163-5.

32. George KS, Wu S. Lipid raft: A floating island of death or survival. Toxicology and applied pharmacology. 2012;259(3):311-9.

33.Verstraeten SV, Jaggers GK, Fraga CG, Oteiza PI. Procyanidins can interact with Caco-2 cell membrane lipid rafts: Involvement of cholesterol. BBA-Biomembranes. 2013;1828 (11):2646-53. 